\title{
The Role of Marketing Knowledge Management in Enhancing Digital Financial Innovation in Commercial Banks:
} Empirical Study

\author{
Hani H. Al-dmour, The Univeristy of Jordan, Jordan \\ Futon Alsfour, The University of Jordan, Jordan \\ Rand Al-Dmour, The University of Jordan, Jordan \\ Noor Majid Saifan, Al Ahliyya Amman University, Jordan
}

\begin{abstract}
This study examines the role of marketing knowledge management (assets and capabilities) in enhancing digital financial innovation through the moderating role of employees' demographic characteristics (age, education, experience, and position) in commercial banks operating in Jordan. To accomplish this aim, a conceptual framework based on knowledge-based theory and literature review was developed. A total of 336 responses to a questionnaire survey were collected from the managers and employees working on commercial banks operating in Jordan. The empirical findings revealed that marketing knowledge management capabilities positively and significantly affect digital financial innovation. The findings also support the moderating effect of only two demographic characteristics: of employee education and position on the relationship between marketing knowledge management and digital financial innovation in commercial banks in Jordan.
\end{abstract}

\section{KEYWORDS}

Business Performance, Digital Financial Innovation, Marketing Knowledge Management

\section{INTRODUCTION}

Applying knowledge efficiently and correctly will help organizations increase their competitive advantage. Facilitating marketing knowledge depends on the presence o knowledge management capabilities (Masa'deh, et al., 2019). These capabilities assist in creating knowledge by integrating/ combining different resources and activities that positively affect competitive advantage (Lungu, 2019). In the business environment context, products, marketplaces, technologies, consumers, rivals, protocols and even communities transform hastily towards knowledge management. They manage, store, and use knowledge and data they have collected overages since they deem knowledge an enabler and intangible asset to organizational success. Also, knowledge serves innovation and sustainable competitive advantages (Fidel et al., 2016). Therefore, management and marketing scholars today appreciate the ability to create and employ knowledge to be the essential source of a firm's better 
performance (Abualoush et al., 2018; Muddaha et al., 2018). Knowledge brings awareness and expertise as cornerstones for economic interests.

As a result, strategic knowledge should be valued as a treasured resource for organizations regardless of the sector and the business in which they operate (Fomani and Sherani, 2012). In addition to the agreed-on benefits, marketing studies agree that marketing knowledge mirrors both explicit and tacit knowledge. It involves strategies with rivals, collaborations, tactics and customer relationships. Furthermore, it indicates the learned lessons from earlier marketing experiences to be employed when developing new products or services while retaining existing customers' relationships (Foumani and Chirani, 2012). Thus, this knowledge ought to be effectively managed (Kermally, 2019). As another side of the discussion, because of its significance, innovation has resulted in various perspectives and led to the introduction of multiple typologies (Chesbrough, 2010). Innovation is considered a crucial factor in wealth creation and organizational competitiveness since it is now outdated to compete based only on financial capital or based on copying others (Efrat et al., 2017).

Marketing knowledge management and competitive advantage are significantly related to each other. This relationship is practically beneficial for business organizations. It is argued that this relationship's importance emanates from the fact that organizing knowledge empowers employees in organizations to enhance their performance in accomplishing their tasks and performing their activities (Ritala et al., 2018; Abualous, et al., 2018). Competency and incremental innovation indicate a solution to reduce sustainable development pressure. Additionally, they develop new capabilities to remove any unwanted business practices and capture business value successfully (Massa and Tucci, 2013; Foumani and Chirani, 2012). On the one hand, merging between innovation and existing business settings is hard to be achieved (Massa and Tucci, 2013; Chesbrough, 2010). On the other hand, as any innovation effort's success is not only the accountability of the innovativeness/actor, the role of social and business contexts needs to be improved and systemic at all levels (Massa and Tucci, 2013; Foumani and Chirani, 2012). Despite the growing recognition of the importance of marketing knowledge management contribution to the promotion of innovation, most of the existing studies have not made clear guidance on unique knowledge processes believed to have the most significant effects (Bueno et al., 2008; Rahimi et al., 2018). Further, research on the interaction between knowledge management and innovation is highly needed (Andreeva and Kianto, 2011; Dahiyat, 2015)

Greater use of technology in banks is allusive to an industry leveraging KM and is ideal for this study. Banks have realized the crucial role of knowledge management in gaining an edge in this competitive field. On the other hand, disruptive innovation holds potential in empowering the bank industry to face unprecedented challenges reflected in the decline of the value provided to clients and shareholders through innovative delivery services/technologies that replace outdated ones. These innovations are neither imitative nor incremental; however, existing services/ technologies should be substituted by ones with more benefits; namely, those that are more valuable, more accessible and more affordable, thereby making them available for much larger segments of customers which might be previously ignored by current competitors (Bolen et al., 2009; Wessel and Christensen, 2012).

Despite the growing body of literature examining knowledge management practices in the banking context, including processes, functions and best practices in KM and the effect of KM on digital financial innovation (e.g., Mciver et al., 2017), the authors of this research noted a lack of empirical studies that examined and validated the impact of marketing knowledge management (assets and capabilities) on digital financial innovation via the moderating role of managers' demographic characteristics (age, sex, education, experience and position) in the context of commercial banking business in Jordan. In general, banking sectors are operating in a dynamic environment at the national and global levels. Consequently, they endeavour to improve their services and administration work by innovative and high-quality products and services to gain a leading position in the market. This research is expected to help bank managers develop new policies and give more considerable attention to marketing knowledge management (assets and capabilities) and digital financial innovation to enhance competitive advantages. 


\section{LITERATURE REVIEW}

\section{Marketing Knowledge Management in Banking Sector}

Marketing knowledge management is part of the knowledge the company possesses and utilizes in its strategies and operations. According to literature, the concept of marketing knowledge management is purely a subset of knowledge management. Researchers defined this concept in terms of other dimensions and concepts in business management. For example, Leposky et al. (2017) defined it as the integration of information. Moreover, Morgan (2012) defined marketing knowledge management as the knowledge resources shared by marketing departments. Akroush and Al-Mohammad (2010) stated that marketing knowledge management is "a discipline that involves the recognition and analysis of obtainable and required marketing-related knowledge assets and capabilities and the ensuing, planning and control of actions to develop both marketing assets and capabilities to fulfil organizational objectives". Marketing knowledge management also refers to that specific scope of knowledge related to organizational marketing processes (Fang et al., 2010). On the other hand, other researchers relate marketing knowledge management to the efforts towards analyzing the trends of the market to understand social aspects, customer behaviors and cultural aspects, and develop brands, products, and different marketing activities (Fang et al., 2010). Hanvanich et al. (2003) argued that with the increasing importance of marketing in today's trade, modern organizations need marketing knowledge management as a significant source of competitive success.

A marketing process consists of different actions and activities according to responsibilities and purposes. For instance, a marketing mix includes various activities designed for the development and management of an organization. Other events are designed to develop, disseminate, and utilise marketing information (Ellis, 2010). However, more developed, and advanced activities are used to implement marketing philosophy and other marketing approaches (Falahati et al., 2013). Some activities are also designed to make marketing philosophy and marketing methods operational throughout the organization. Such a variety of marketing activities requires the existence and optimization of relevant assets and growth abilities of MKM to achieve organizational goals. Faraji (2011) argued that if financial firms are moving slower than their surroundings, they are subject to collapse. Business managers need to manage marketing knowledge and information to make the necessary decisions. Such management leads to a decrease in errors and duplication and increases problem-solving and decision-making speed. This will reduce costs and lead to more effective relationships and better services provided to customers and achieve employee satisfaction. On the other hand, it should be noted that in today's economy, the interest of banks and the banking industry in improved technology has intensified competition among banks and meanwhile, banks are successful and have excellent performance (Liebl, 2015). An organization's marketing assets and capabilities have been described as a significant determinant of business performance and are a potential source of achieving competitive advantage:

(1) Built-in marketing assets are these assets acquired by the organization over time. Examples of built-in marketing assets are the organization's name and image, which may drive customers' purchasing decisions, achieve better satisfaction levels, and improve loyalty (Falahati et al., 2013). Growing sales' volume increases market share. Investment in developing an organization's name and brand image should undeniably influence its competitive situation in the market, thereby positively impacting its performance (Fang et al., 2010).

(2) Invested-in marketing assets refer to assets expected to be developed through investments extended by the organization. This concept is defined as "the existing assets observing substantial investment, or new assets being invested-in" (Akroush and Al-Mohammad, 2010; Morgan, 2012). Owning built-in marketing assets overtime is based on the businesses needed to invest in developing old assets and acquiring new ones which are the "invested-in marketing assets". In other words, even though most of an organization's assets can be built-in, continuous investment 
is needed to develop them to competitively deal with changes in the market environment (Akroush and Al-Mohammad, 2010).

(3) Internal marketing capabilities are viewed as the internal processes associated with providing value-added products and services that meet competitive requirements. Internal marketing capabilities induce functional integration, finances, strategic management, marketing management and ongoing operations' management (Akroush, 2006). Internal marketing capabilities have a positive impact on business performance. These capabilities provide organizational skills and distribute high-quality products and services that will positively impact customer satisfaction, improve their loyalty and improve organizational performance (Morgan, 2012; Akroush and Al-Mohammad, 2010).

(4) External marketing capabilities are defined as "the external processes concerned with understanding the organization's external environment with all its factors". Examples of external marketing capabilities are opponents, customers, service suppliers and distributors. Organizations must carry out a comprehensive analysis of the macro-industry characteristics through analyzing and understanding all the relevant dimensions (Morgan, 2012).

\section{Digital Financial Innovation}

Mansur et al. (2018) defined organizational innovation as the competitive advantage obtained from qualified human resources, where marketing knowledge enables organizations to compete based on quality and innovation. Crossan and Apaydin (2010) argued that innovation is the "production and adoption, assimilation and exploitation of value-added novelty in economic and social spheres; renewal and enlargement of products, services and markets; development of new methods of production; and establishment of new management systems. It is both a process and an outcome." Organizations tend to expand their innovative actions to leverage their performance and profitability. Such expansion needs different strategies, such as managing knowledge within the organization and using such knowledge in their different operations. In other words, innovation is associated with introducing new techniques, methods, techniques, or processes into the production chain to provide remarkable benefits and advantages to customers in terms of products and services (Oliva and Kotabe 2019). When financial innovation mentioned in the broad sense, it is evident that it encompasses establishing new financial institutions, technologies, instruments and tools, processes, products, and services. Examples are online banking, phone banking and different information and communication technology (ICT) applications (Edwards-Schachter, 2018). Gomber et al. (2017) argued that the term digital finance innovation includes a wide variety of novel financial software programs, businesses, products, and services to enable customers to interact and communicate with financial institutions more quickly and more efficiently. Something similar was stated by Korir et al. (2015) who indicated that digital financial innovation has to do with introducing new instruments and tools to be utilized by financial institutions to raise their level of effectiveness and efficiency in terms of the services offered by these institutions to their customers.

Digital finance covers a wide range of financial fields. Examples are payments, remittances, savings and investments, personal financial management, trade, and invoice finance. Digital financial innovative services can be made available to large firms, SMEs, and individuals. According to Klapper et al. (2016), digital financial innovation also encompasses diverse financial processes, such as capital market activities, banking system connectivity, credit scoring, asset securitization, risk management and trade processing. It also extends to cover other financial processes, like middle- and back-office reporting, customer service, collections, and recovery and compliance with the so-called AntiMoney Laundering-Know Your Customer (AML-KYC). It can be argued that financial institutions, particularly banks, have improved their performance and profitability, relying on financial innovation (Scott et al., 2017). Banking has witnessed a real revolution in performed financial transactions, as stated by Yin and Zhengzheng (2010), who found out that Chinese commercial banks have remarkably 
enhanced their financial operations by utilizing digital financial innovation. It was revealed that the Tunisian banking industry has benefited from the positive, significant relationship between return on assets (ROA) and financial product innovation, Mabrouk and Mamoghli, (2016). In this study, digital financial innovations can be grouped as new products: subprime mortgages or services, internet banking and others. Digital financial services (DFSs) are significant financial resolutions for cultivating financial inclusion (Buckley and Malady, 2015; Akhisar et al., 2015). Digital financial are provided to the underprivileged using advanced skills, digital platforms, and electronic money models (Scott et al., 2017; David-West et al., 2018; Nguena, 2019).

\section{Marketing Knowledge Management and Digital Financial Innovation}

Several scholars have widely discussed the relationship between knowledge management and technological innovation (e.g., Kör and Maden, 2013; Waribugo et al., 2016; Talat, 2018). Most researchers have agreed that innovation depends heavily on the knowledge and the way of managing it. Today, knowledge management becomes an essential managerial task that helps organizations in shaping a sound innovation strategy. Knowledge management has been recognized as a tool to help an organization identify gaps in knowledge and provide ways to fill up these gaps to aid organizational innovation (Akram, 2011). Through knowledge management, managers can use pre-programmed models based on integrative knowledge of past experiences and ask for updated information while considering alternative solutions and stimulating innovative proposals. Al Rubaiee et al. (2015) conducted a study that aimed at developing a better understanding of the relationships between organizational performance, organizational innovation, and knowledge management processes in the context of telecommunication and information technology industry in Amman. The study was exploratory and quantitative. The results of the study revealed a positive and robust impact of knowledge management processes on organizational innovation.

To achieve successful MKM implementation and technological innovation, organizations need to determine the role of the employees' characteristics; however, studies that empirically and specifically examined the impact of employees' demographic characteristics on the relationship between marketing knowledge management (capabilities and assets) and product innovation have rarely been available. Harem and Al-Saae'd (2006) indicated that knowledge management practices were influenced by their characteristics (age, experience, education position). Al-Dmour et al. (2020) argued that managers' attitudes toward knowledge management are influenced by their experience and position factors. Also, Ababneh's study (2008) showed that knowledge management has a strong positive correlation with organizational innovation and that employees' demographic variables significantly impact practising each KM dimension. However, other studies showed that age, education, and position do not affect knowledge management behaviour, (e.g., Ismail 2006; Ojha 2005; and Watson \& Hewett 2006).

\section{Research Model and Hypotheses}

The major elements of this research are established based on preceding literature, either theoretically or empirically. Indeed, this study used variables that are common in knowledge management literature. Figure 1 represents a study model that shows the independent variables within the construct of marketing knowledge management capabilities and the dependent variable (digital financial innovation), and the proposed relationship between them. The current research considers four independent variables within marketing knowledge management capabilities and one dependent variable (digital financial innovation). Further, marketing knowledge management capabilities include built-in marketing assets, invested-in marketing assets, internal marketing capabilities and external marketing capabilities. (Muddaha et al., 2018; Akroush and Al-Mohammad, 2010) and digital financial innovation. This research is based on knowledge-based theory (Grant, 1996) and financial innovation (Silber 1993). The knowledge-based theory assumes that knowledge as an intangible asset resource is an essential strength whose proper utilization could go a long way in offering long-term sustainable 
Figure 1.

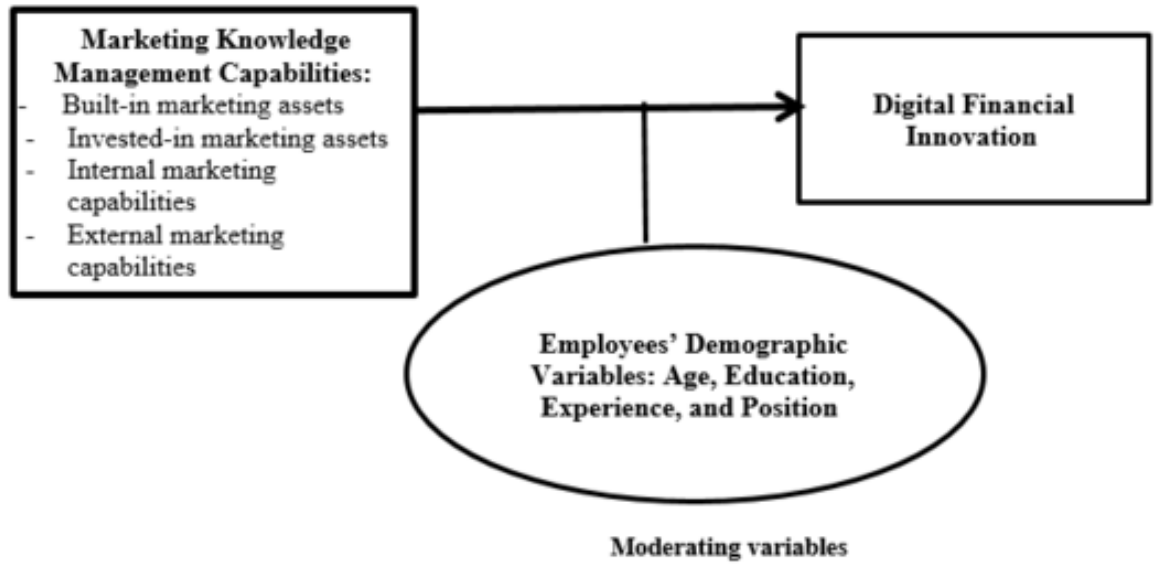

competitiveness. An essential aspect of this theory is that the primary source of competitiveness is applying knowledge and not just in possession of knowledge.

On the other hand, financial innovation theory viewed that improving corporate performance is the critical factor for financial institutions to engage in digital financial innovation through service delivery efficiency (Silber, 1993). Innovation harnesses the ICT capabilities to create new banking services and new media for offering services. Theoretical background and knowledge-based theory and the relevant literature on marketing knowledge management and digital financial innovation were reviewed and integrated to develop a model to guide this study.

Based on the study model and the study questions, the following hypotheses are formulated in the Jordanian environment business context:

Ho1: There is no significant impact of marketing knowledge management capabilities (built-in marketing assets, invested-in marketing assets, internal marketing capabilities and external marketing capabilities) on digital financial innovation in Jordanian commercial banks.

Ho 2. Employees' demographic variables (age, education, experience, and position) do not significantly moderate the relationship between marketing knowledge management capabilities and digital financial innovation.

\section{RESEARCH METHODOLOGY}

The research employs a quantitative method with an exploratory and descriptive design. A survey questionnaire was employed to collect data to confirm the conceptual research model and investigate the research hypotheses. This research's target population consisted of all the banks operating in the Jordanian market registered at the Association of Banks in Jordan up to 2019. 13 commercial banks are operating in Jordan, and all agreed to participate in this study. The participants (i.e., the sample) in this research were specified as all marketing managers and employees at banks' headquarters and branch working for those banks. The researchers distributed a total of 602 surveys using both online and paper-based questionnaires. The number of the returned instruments was 492. After eliminating any incomplete or improperly filled questionnaires, the valid usable questionnaires for further analysis were 336 (55.8\% of the total), which is a decent rate in comparison with the lengthy approvals and 
authorization processes followed by the researchers to distribute and share the survey questionnaire to the targeted bankers.

The questionnaire's content (measures) was mainly selected and adopted from relevant previous studies. The independent variables: "components of marketing knowledge management" were measured using a 5-point scale developed by Akroush and Al-Mohammad (2010), Davoudi et al. (2018) and Prifti and Alimehmeti (2017). The dependent variable "Digital financial innovation" was measured using a 5-point scale developed by Girniene (2013), Ramona-Diana and Bolisani (2016), Kör and Maden (2012). For construct validation, the questionnaire content was modified to the practice of Jordanian business culture context based on a pilot study and feedback from five professional academic staff members in this filed.

\section{Respondents' Demographic Profile}

In this study, $57 \%$ of the respondents were males and $33 \%$ in the age group between 40 and 49 . About $75 \%$ of the respondents have a bachelor's degree in education, and $39 \%$ have an experience of fewer than ten years, while about $47 \%$ of them were acting as divisional/branch level managers in Jordanian's commercial banks. Table (1) summarizes the demographic characteristics of the respondents.

\section{Descriptive Analysis}

Table 1. The demographic characteristics of the respondents

\begin{tabular}{|c|c|c|c|}
\hline Characteristics & Category & Frequency & $\begin{array}{r}\text { Per } \\
\text { cent }(\%)\end{array}$ \\
\hline \multirow[t]{4}{*}{ Age } & 24- 29 years & 84 & 25 \\
\hline & $30-39$ years & 95 & 28 \\
\hline & $40-49$ years & 110 & 33 \\
\hline & 50 years and above & 47 & 14 \\
\hline \multirow[t]{3}{*}{ Education } & $\begin{array}{l}\text { Secondary and } \\
\text { diploma }\end{array}$ & 27 & 08 \\
\hline & Bachelor's degree & 254 & 75 \\
\hline & $\begin{array}{l}\text { Graduate degree (MA } \\
\text { or } \mathrm{PhD} \text { ) }\end{array}$ & 57 & 17 \\
\hline \multirow[t]{3}{*}{ Experience } & Less than 10 years & 132 & 39 \\
\hline & 11-15 years & 121 & 36 \\
\hline & 16 years and above & 83 & 25 \\
\hline \multirow[t]{3}{*}{ Position } & $\begin{array}{l}\text { Divisional /branch } \\
\text { manager }\end{array}$ & 157 & 47 \\
\hline & $\begin{array}{l}\text { Head of department/ } \\
\text { executive }\end{array}$ & 99 & 29 \\
\hline & $\begin{array}{l}\text { Chief officer/lower } \\
\text { level }\end{array}$ & 80 & 24 \\
\hline
\end{tabular}

The mean, standard deviation, level of importance, skewness, and kurtosis were calculated for all the measurements to illustrate the extent of the significance of variables to the sampled respondents. The descriptive statistics offered in Table 2 pointed to a positive disposition towards the items measured. The mean values indicate a narrow spread around the mean. Also, most items' mean values were 
greater than the midpoint (3) and ranged from 4.30 to 4.38 . The level of every item was calculated by the following method: (highest point in Likert scale - lowest point in Likert scale) / number of levels used $=(5-1) / 5=0.80$, where (1-1.80) indicating "very low", (1.81-2.60) indicating "low", (2.61-3.40) indicating "moderate", (3.41-4.20) indicating "high" and (4.21-5) indicating "very high".

Table 2. Means and standard deviations

\begin{tabular}{|c|c|c|c|c|c|}
\hline Constructs & Mean & $\begin{array}{c}\text { Standard } \\
\text { Deviation }\end{array}$ & $\begin{array}{c}\text { Level of } \\
\text { importance }\end{array}$ & Skewness & Kurtosis \\
\hline \multicolumn{7}{|c|}{$\begin{array}{c}\text { Marketing Knowledge Management Capabilities } \\
\text { Built-in } \\
\text { marketing assets }\end{array}$} & 4.38 & 0.591 & $87.6 \%$ & -1.806 & 5.090 \\
\hline $\begin{array}{c}\text { Invested-in } \\
\text { marketing assets }\end{array}$ & 4.34 & 0.575 & $86.8 \%$ & -1.774 & 5.280 \\
\hline $\begin{array}{c}\text { Internal } \\
\text { marketing } \\
\text { capabilities }\end{array}$ & 4.32 & 0.572 & $86.4 \%$ & -1.501 & 4.682 \\
\hline $\begin{array}{c}\text { External } \\
\text { marketing } \\
\text { capabilities }\end{array}$ & 4.33 & 0.611 & $86.6 \%$ & -1.402 & 3.364 \\
\hline \multicolumn{1}{|c|}{ All } & 4.34 & 0.534 & $86.8 \%$ & -1.697 & 5.631 \\
\hline $\begin{array}{c}\text { Digital } \\
\text { Financial } \\
\text { Innovation }\end{array}$ & 4.30 & 0.551 & $86.0 \%$ & -1.565 & \\
\hline
\end{tabular}

After that, the items were being ordered by their means (Sekaran,2003). After careful assessment using skewness and kurtosis, the data was generally distributed for normality test. Indeed, skewness and kurtosis indicated normal distribution, since most of the values were inside the adequate range for normality (i.e., -1.0 to +1.0 ) for skewness and less than 10 for kurtosis (Hair et al., 2010).

\section{DATA ANALYSIS}

\section{The Exploratory Factor Analysis (EFA)}

The aim of using the exploratory factor analysis is to reduce the number of variables in each MKM (i.e., Built-in marketing assets, Invested-in marketing assets; Internal marketing capabilities and external marketing capabilities) to facilitate further regression analysis. PCA is also deemed suitable for overcoming multicollinearity problems. In this study, data was cheeked to determine whether it is appropriate for factor analysis. The factor analysis findings have been tested using eigenvalues, interpretability, and internal consistency, as suggested by Hair et al., (2010). Items having eigenvalues above (1) and factor loadings under (0.40) have been determined.

Thereby, items having a weak or no relationship to each other are ignored (Hair et al., 2010). In this study, marketing knowledge management was measured using (29) items, as presented in Table 4. An inspection of the correlation matrix indicates that all the correlations were above the acceptable level of 0.40. Subsequent KMO and Bartlett's test resulted in a significant level of probability $(\mathrm{P}>0.000)$ and a high KMO statistic of (0.794), confirming that all the factor analysis could be carried out, as (79.0\%) of the variance in the data can be explained by this construct, as presented in Table.3. 
Table 3. KMO and Bartlett's test

\begin{tabular}{|l|l|l|}
\hline \multicolumn{2}{|c|}{ KMO and Bartlett's Test } \\
\hline \multirow{2}{*}{ Kaiser-Meyer-Olkin Measure of Sampling Adequacy } & 0.893 \\
\hline \multirow{3}{*}{ Bartlett's Test of Sphericity } & Approx. Chi-Square & 856.038 \\
\cline { 2 - 3 } & DF & 314 \\
\cline { 2 - 3 } & Sig. & 0.000 \\
\hline
\end{tabular}

Table 4. Total variance explained

\begin{tabular}{|c|c|c|c|}
\hline \multirow{2}{*}{ Component/ Factor } & \multicolumn{3}{|c|}{ Rotation Sums of Squared Loadings } \\
\cline { 2 - 4 } & Eigenvalue & \% of Variance & Cumulative \% \\
\hline 1 & 5.152 & 23.713 & 23.713 \\
\hline 2 & 2.604 & 19.681 & 43.394 \\
\hline 3 & 1.159 & 14.785 & 58.179 \\
\hline 4 & 1.231 & 11.932 & 70.111 \\
\hline
\end{tabular}

The exploratory factor analysis results in Table (5) indicate that four factors could be extracted from the variables of marketing knowledge management. The first factor, which accounts for (23.713 of the variance with loadings ranging from 0.61 to 0.83 , can be identified as a "Built-in marketing assets" factor. The second factor, which explains $19.681 \%$ of the variance with loadings ranging from 0.63 to 0.79 , can be labelled as "Invested in marketing assets" factor and the third one, which accounts for (14.785\%) of the variance can be named as "Internal marketing capabilities" factor. Furthermore, the last one is called "external marketing capabilities" which accounts for (11.932) The combination of these factors accounts for $(70.111 \%$ ) of the total variance in the questionnaire data as can be shown in Table (5). In statistics, multicollinearity is a phenomenon in multiple regression analysis; it arises if there is a high correlation coefficient (positive or negative) between two or more independent variables.

Multicollinearity can be assessed by the most widely used measures: Tolerance and Variance Inflation Factor (VIF), which is the proportion of variance in the independent variable that is not explained by its relationships with the other independent variables. Hair et al. (2012) stated that the minimum cut-off value for tolerance is typically $(0.10)$; a tolerance value less than 0.10 should be investigated further. On the other hand, the Variance Inflation Factor (VIF) determines how much the variance of regression coefficients is inflated by multicollinearity problems, noting that (VIF) value is favorable when being less than five and in more relaxed criteria when being less than 10 (Hair et al., 2010). From this perspective, the multicollinearity test for the four factors (Built-in marketing assets, Invested-in marketing assets; Internal marketing capabilities and external marketing capabilities) was accomplished, where all (VIF) values were less than five and less than 10), while tolerance values were more than (0.10). Consequently, there is no collinearity within the collected data, which reinforced the model by avoiding having interchangeable beta values between independent variables and indicates that there was no bias. 
Table 5. Main factors underlying the knowledge management process

\begin{tabular}{|c|c|c|c|}
\hline Code & Items (variables) & Loadings & $\begin{array}{r}\text { Cronbach's } \\
\text { Alpha }\end{array}$ \\
\hline & \multicolumn{2}{|l|}{ Factor 1 Built-in Marketing Assets } & 0.760 \\
\hline BM3 & Developing new banking products. & 0.658 & \\
\hline BM5 & Developing customer service quality. & 0.615 & \\
\hline BM2 & Developing a customer service relationship. & 0.712 & \\
\hline BM1 & Building a strong brand image of the bank. & 0.839 & \\
\hline BM8 & Developing bank promotion and customer education. & 0.707 & \\
\hline BM6 & Improving the banking channel of distribution. & 0.744 & \\
\hline BM7 & Building employees' skills, capabilities, and knowledge. & 0.663 & \\
\hline \multirow[t]{2}{*}{ BM4 } & $\begin{array}{l}\text { Building technological abilities, e.g., information } \\
\text { technology. }\end{array}$ & 0.719 & \\
\hline & Factor 2: Invested in Marketing Assets & & 0.831 \\
\hline IM3 & Strategic marketing planning. & 0.699 & \\
\hline IM5 & Market segmentation. & 0.645 & \\
\hline IM6 & Building reputation or image. & 0.709 & \\
\hline IM2 & Service quality. & 0.630 & \\
\hline IM1 & Technological processes. & 0.764 & \\
\hline IM4 & Service delivery process activities. & 0.795 & \\
\hline IM8 & Market place and customer knowledge. & 0.749 & \\
\hline \multirow[t]{2}{*}{ IM7 } & Serving customers and handling their complaints. & 0.730 & \\
\hline & Factor 3: Internal Marketing Capabilities & & 0.856 \\
\hline CM1 & Integrated marketing programs. & 0.704 & \\
\hline CM4 & Innovating and developing new banking services. & 0.741 & \\
\hline CM5 & Superior pricing capabilities. & 0.729 & \\
\hline CM6 & Marketing communication capabilities. & 0.585 & \\
\hline CM4 & Distribution capabilities. & 0.740 & \\
\hline \multirow[t]{2}{*}{$\mathrm{CM} 2$} & $\begin{array}{l}\text { Superior skills, abilities, and knowledge of marketing and } \\
\text { technical specialists. }\end{array}$ & 0.721 & \\
\hline & Factor 4: External Marketing Capabilities & & 0.891 \\
\hline $\mathrm{EC} 1$ & Understanding of customer wants and needs. & 0.697 & \\
\hline EC3 & $\begin{array}{l}\text { Creating, sustaining, and enhancing relationships with the } \\
\text { firm's customers, financial institutions, etc. }\end{array}$ & 0.757 & \\
\hline $\mathrm{EC} 2$ & $\begin{array}{l}\text { Conducting a comprehensive analysis of the external } \\
\text { business environment. }\end{array}$ & 0.808 & \\
\hline EC5 & Analyze information to anticipate market requirements & 0.778 & \\
\hline EC6 & $\begin{array}{l}\text { Matching the bank's distinguished competencies with } \\
\text { external opportunities in the marketplace. }\end{array}$ & 0.715 & \\
\hline $\mathrm{EC} 4$ & Identifying lead strategic activities. & 0.619 & \\
\hline
\end{tabular}




\section{HYPOTHESES TESTING}

This part of the study focuses on testing the study hypotheses, which were developed to assess the relationships between independent and dependent variables. Multiple regression was used to accept or reject the research hypotheses. Two regression analyses were performed to determine the relationships between the independent variables and the dependent variable and the effect of the moderator. Interaction testing can show the moderator effect (Hair et al., 2010). A moderator is a variable that strengthens or weakens the relationship between dependent and independent variables. Statistically, moderation is an interaction between the independent and moderator variables on the relationship with the dependent variable (Hair et al., 2010).

Multiple regressions enable to test the effect of many different factors (independent variables) on a particular outcome (dependent variable) at the same time. In the beginning, this study used the model summary, which consists of "coefficient of determination $\left(\mathrm{R}^{2}\right)$ " to measure how much that independent variables (Built-in marketing assets, Invested-in marketing assets; Internal marketing capabilities and external marketing capabilities) can justify from the problem in the dependent variable (Digital financial innovation). $\mathrm{R}^{2}$ falls between 0 and 1 . Higher values of $\mathrm{R}^{2}$ improved the regression model fit with the observations. Furthermore, analysis of variance (ANOVA) was used to assess the model fit and its overall significance to test the hypotheses (Ho1 and Ho2).

\section{The First Hypothesis}

Ho1: There is no significant impact of marketing knowledge management capabilities (built-in marketing assets, invested-in marketing assets, internal marketing capabilities and external marketing capabilities) on digital financial innovation in Jordanian commercial banks.

After conducting a multiple regression test to examine the correlation, the relationship between the variables $(\mathrm{R})$ is 0.751 , which means a significant relationship between the four main factors of marketing knowledge management and digital financial innovation. The $\mathrm{R}^{2}$ value indicates that the four factors (Built-in marketing assets, Invested-in marketing assets; Internal marketing capabilities and external marketing capabilities) are responsible for about $56 \%$ of the change in commercial banks' level of innovation.

Table 6. Model summary

\begin{tabular}{|c|c|c|c|c|c|c|c|c|c|}
\hline \multirow[b]{2}{*}{ Model } & \multirow[b]{2}{*}{$\mathbf{R}$} & \multirow[b]{2}{*}{ R Square } & \multirow[b]{2}{*}{ Adjusted R Square } & \multirow{2}{*}{$\begin{array}{l}\text { Std. The } \\
\text { errorof the } \\
\text { Estimate }\end{array}$} & \multicolumn{5}{|c|}{ ANOVA } \\
\hline & & & & & $\begin{array}{l}\text { Sum of } \\
\text { Squares }\end{array}$ & Df & $\begin{array}{c}\text { Mean } \\
\text { Square }\end{array}$ & $\mathbf{F}$ & Sig. \\
\hline 1 & $0.751 a$ & 0.564 & 0.549 & 0.36751 & 23.477 & 3 & 9.188 & 5634 & 0.000 \\
\hline
\end{tabular}

By implementing the level of significance (0.05) to reject or accept the first hypothesis; the F- value for the collected primary data was 9.188 , which is significant at the level of $\mathrm{p}<0.05$ (sig. $=$ 0.000 ). It means that there is a statistically significant relationship between the marketing knowledge management functions (Built-in marketing assets, Invested-in marketing assets; Internal marketing capabilities and external marketing capabilities) on digital financial innovation. Table 7started with an estimation of beta for each independent variable. It gives a measure of the contribution of each variable to the model. Clearly, a large value shows that a unit change in the independent variable has a large effect on the dependent variable; internal marketing capabilities represented the highest beta 
values, which was 0.462 . Therefore, internal marketing capabilities have the highest contributions in the research model.

Table 7. Coefficients for variables

\begin{tabular}{|c|c|c|c|c|c|c|}
\hline \multicolumn{7}{|c|}{ Coefficients } \\
\hline \multirow{2}{*}{\multicolumn{2}{|c|}{ Model }} & \multicolumn{2}{|c|}{$\begin{array}{l}\text { Unstandardized } \\
\text { Coefficients }\end{array}$} & \multirow{2}{*}{$\begin{array}{c}\begin{array}{c}\text { Standardized } \\
\text { Coefficients }\end{array} \\
\text { Beta }\end{array}$} & \multirow[t]{2}{*}{$\mathbf{T}$} & \multirow[t]{2}{*}{ Sig. } \\
\hline & & Beta & $\begin{array}{c}\text { Std. } \\
\text { Error }\end{array}$ & & & \\
\hline \multirow{5}{*}{11} & (Constant) & 2.143 & 0.232 & & 11.087 & 0.000 \\
\hline & $\begin{array}{c}\text { Built-in } \\
\text { marketing assets }\end{array}$ & 0.161 & 0.042 & 0.213 & 4.177 & 0.000 \\
\hline & $\begin{array}{l}\quad \text { Internal } \\
\text { marketing } \\
\text { capabilities }\end{array}$ & 0.311 & 0.046 & 0.462 & 6.876 & 0.000 \\
\hline & $\begin{array}{l}\quad \text { Invested } \\
\text { in marketing } \\
\text { assets }\end{array}$ & 0.242 & 0.036 & 0.154 & 4.354 & 0.000 \\
\hline & $\begin{array}{l}\quad \text { External } \\
\text { marketing } \\
\text { capabilities }\end{array}$ & 0.101 & 0.031 & 0.099 & 2.180 & 0.031 \\
\hline
\end{tabular}

The second part of Table 7 demonstrates $\mathrm{T}$ and sig. Values, which give a rough indication of the relationship of each independent variable with the dependent variable. For instance, a big absolute (T) value and a small $(\mathrm{p})$ value indicate that a predictor variable has a large effect on the criterion variable.

\section{The Second Hypothesis}

Ho 2. Employees' demographic variables (age, education, experience, and position) do not significantly moderate the relationship between marketing knowledge management capabilities and digital financial innovation.

Moderators are variables that can modify the relationship directly between independent and dependent variables. Hierarchal regression analysis was performed to examine the moderation effect of the respondents' demographic characteristics (age, education, and experience and position) on the relationship between the independent variables and the dependent variable. It shows that: $\mathrm{R}$ square $=$ 75.3 means that $75.3 \%$ of the dependent variable variation is explained by the independent variables and $p=000<0.01$ which is very significant, implying that the model is adequate. Table 8 shows respondents' demographic characteristics (age, education, experience, and position) as moderators for the relationship between marketing knowledge management and digital financial innovation. Based on the results, only two respondents" demographic characteristics; position and education were positively significant ( $\mathrm{p} £ 0.05$ ) as moderators with $\mathrm{R}$ square change of 0.016 and 0.020 , respectively. However, age and experience were found insignificant as moderators in the relationship between marketing knowledge management and digital financial innovation. Therefore, Ho 2 is partially accepted. This result implies that respondents" education and position factors could improve the prediction level (the 
rate of explanation) of the relationship between MKM and digital financial innovation. The explanation power has increased from 0.751 to 0.778 , with the existence of these two demographic factors.

Table 8. Hierarchical regression results of the effects of respondents' demographic characteristics as moderators

\begin{tabular}{|c|c|c|c|c|c|}
\hline $\begin{array}{c}\text { Selected } \\
\text { variable }\end{array}$ & Model 1 & Model 2 & Model3 & Model 4 & Model 5 \\
\hline $\begin{array}{c}\text { MKM } \\
\text { management }\end{array}$ & $0.751^{\mathrm{a}^{* * *}}$ & $\cdot$ & & & \\
\hline Age & & $0.761^{\mathrm{b}^{* * *}}$ & & & \\
\hline Position & & & $0.767^{\text {**** }}$ & & \\
\hline Experience & & & & $0.770^{\mathrm{d}^{* * *}}$ & \\
\hline Education & & & & & $0.778 \mathrm{e}^{* * *}$ \\
\hline R Square & 0.5647 & 0.579 & 0.588 & 0592 & 0.605 \\
\hline $\begin{array}{c}\text { Adjusted R } \\
\text { Square }\end{array}$ & 0.525 & 0.527 & 0.529 & 0.539 & 0.578 \\
\hline $\begin{array}{c}\text { R Square } \\
\text { change }\end{array}$ & & 0.003 & 0.018 & 0.016 & 0.007 \\
\hline F sig. change & 43.111 & 1.222 & 3.298 & 1.058 & $16.344^{* *}$ \\
\hline Sig. & $\mathbf{0 . 0 0 0 * * *}$ & $\mathbf{0 . 3 4 4}$ & $\mathbf{0 . 0 3 1}$ & $\mathbf{0 . 1 4 2}$ & $\mathbf{0 . 0 2 2 1 *}$ \\
\hline
\end{tabular}

${ }^{*} p £ 0.05^{* *} ; p £ 0.01 ;{ }^{* * *} p £ .001$

\section{DISCUSSION, CONTRIBUTIONS, AND IMPLICATIONS}

This study aims to explore the effect of marketing knowledge management (Built-in marketing assets, Invested-in marketing assets; Internal marketing capabilities and external marketing capabilities) upon digital financial innovation via the moderating role of bank employees' demographic characteristics (age, education, experience and position) in commercial banks operating in Jordan. Testing the research hypotheses has led to results and conclusions compared with previous general findings and observations. Three factors were extracted from the 29 items of marketing knowledge managements, which were: (1) Built-in marketing assets, (2) Invested-in marketing assets; (3) Internal marketing capabilities and (4) external marketing capabilities and subsequently used to answer the research questions by using multiple regression analysis. This result is consistent with previous research (e.g., Akorash, 2006; Fahy et al.; Morgan, 2012; Tnorbi and El-Den, (2017).

This study's first objective is to explore to which extent commercial banks operating in Jordan are employing marketing management: assets and capabilities to enhance digital financial innovation. The findings indicate that the extent of investing in marketing knowledge management of (1) Built-in marketing assets, (2) Invested-in marketing assets; (3) Internal marketing capabilities and (4) external marketing capabilities by commercial banks operating in Jordan are considered acceptable ((i.e., $86 \%$ or 4.34, Table 2), since their mean is more than the mean of the scale, which is 3 (mean of the scale $=\Sigma$ Degrees of the scale $1+2+3+4+5 / 5=3.00$ ). It appears that commercial banks in Jordan are fully aware of the importance of using marketing knowledge management.

The second objective of the study was to examine and validate the impact of marketing knowledge management capabilities and digital financial innovation in Jordanian commercial banks. The analysis provides empirical evidence regarding marketing knowledge management's effect on digital financial innovation (hypotheses $\mathrm{H}_{1}$ )). The results for this hypothesis significantly and positively supported the linkage between marketing knowledge management and digital financial innovation (Rezaee and Jafari 
2015; Alrubaiee et al. 2015, Byukusenge et al. 2016, Nawab et al. 2015, Nowacki, and Bachnik, (016; Al-Dmour et al., 2020). This could be attributed to the fact that information technology is used and that there is some form of knowledge being acquired and distributed by commercial banks operating in Jordan. In today's banking industry environment characterized by rapid and continuous changes, empirically analyzing marketing knowledge management capabilities and innovation concepts is critical because of these concepts' importance in creating competitive advantages.

The third objective was to examine the effect of bank employees' demographic characteristics (age, education, experience, and position) as a moderating factor in the relationship between marketing knowledge management and digital financial innovation. The study's findings indicate that only two employees' demographic characteristics; education and position play essential roles as moderating factors in the relationship between marketing knowledge management capabilities and level of digital financial innovation in commercial banks of Jordan, while age, experience does not. This result implies that employees with higher education and position positively improve the relationship between marketing knowledge management capabilities and digital financial innovation in commercial banks in Jordan, while age and experience were insignificant. This result is supported by previous studies, such as Al-Dmour et al. (2020).

This study fills the literature gap regarding a comprehensive understanding of the relationships between marketing knowledge management (assets and capabilities), and digital financial innovation. Also, it contributes to the literature and knowledge-based theory and fanatical innovation theory by empirically analyzing the relationship between marketing knowledge management capabilities and digital financial innovation. Through managing knowledge virtually, commercial banks can improve digital financial innovation. Therefore, marketing knowledge management (MKM): assets and capabilities (built-in marketing assets, invested-in marketing assets, internal marketing capabilities) are external marketing capabilities been considered sufficient means of enhancing digital financial innovation.

The study also significantly contributes to supporting knowledge-based theory and financial innovation theory by supporting the links between marketing knowledge management (assets and capabilities) and digital financial innovation via the moderating effect of the banks' employees' demographic characteristics their education and position. Based on the research findings, the study concludes that marketing knowledge management (assets and capabilities) plays a vital role in enhancing commercial banks' digital financial innovation in Jordan. Marketing knowledge management capabilities could be viewed as an essential attribute to increase innovation. Therefore, marketing managers of commercial banks in Jordan should understand and focus on their available marketing assets and capabilities as significant components of any effort to manage such a critical knowledge scope. They should also use and manage their knowledge marketing management assets and capabilities more efficiently and be more technology innovation-oriented, which will improve their competitive advantages.

Marketing knowledge management (MKM): assets and capabilities should be integrated and combined to enhance commercial banks' digital financial innovation. Managers of commercial banks in Jordan should improve marketing knowledge assets and capabilities in their organizations. They should apply intellectual capital development and knowledge dissemination to a greater extent because of their strong influence on digital financial innovation. The managers of commercial banks in Jordan should integrate and fully utilize knowledge management to develop and enhance digital financial innovation's effectiveness in their organizations. Hence, managers in commercial banks need to recognize the importance of practical knowledge management practices to enhance their level of digital financial innovation. Furthermore, in similar countries, the commercial banking sector can use this study's outcomes to understand better the practices of knowledge management in banks and the skills acquired by or existing in individuals working in the organization. The study findings are also helpful to cultivate a knowledge-oriented environment. Banks should consider promoting a culture of practising knowledge management among their managers and employees by 
motivating and training them to promote innovation. Because this study has a cultural context, it is recommended for future studies to be extended on other types of service sectors. Therefore, we could see the differences between marketing knowledge management capabilities on innovation on new entry companies and a new environment. Therefore, further research is needed to be conducted in other business environments to improve reliability and validity. 


\section{REFERENCES}

Ababneh, R. I. \& Edwan, M. (2008). The impact of knowledge management and organization learning on organizational innovation: The case of Greater Amman Municipality in Jordan. Academic Press.

Abualoush, S., Masa'deh, R. E., Bataineh, K., \& Alrowwad, A. (2018). The knowledge management process and intellectual capital as intermediary variables between knowledge management infrastructure and organization performance. Interdisciplinary Journal of Information, Knowledge and Management, 13, 279-309.

Akram, Siddiqui, Nawaz, Ghauri, \& Cheema. (2011). Role of knowledge management to bring innovation: An integrated approach. International Bulletin of Business Administration, 11, 121-134.

Akroush, M. (2006). The Services Marketing Mix Paradigm: Is It Still Appropriate for Today's Service Businesses? Al-Balqa' Journal for Research and Studies, 11(2), 49-74.

Akroush, M., \& Al-Mohammad, S. (2010). The effect of marketing knowledge management on organizational performance: An empirical investigation of telecommunication organizations in Jordan. International Journal of Emerging Markets, 5(1), 38-77. doi:10.1108/17468801011018266

Al-Dmour, A. (2018). The Impact of the Accounting Information System's Reliability upon the Business Performance via the Mediating Role of the Quality of Financial Reporting. The International Journal of Accounting and Business Society, 26(1), 78-111. doi:10.21776/ub.ijabs.2018.26.1.5

Al-Dmour, A., Al-Dmour, R., \& Rababeh, N. (2020). The impact of knowledge management practice on digital financial innovation: The role of bank managers. VINE Journal of Information and Knowledge Management Systems, 50(3), 45-67.

Al-Hakim, L. (Ed.). (2010). Innovation in Business and Enterprise: Technologies and Frameworks: Technologies and Frameworks. IGI Global. doi:10.4018/978-1-61520-643-8

Alrowwad, A. A., Obeidat, B. Y., \& Aqqad, N. (2017). The impact of transformational leadership on organizational performance via the mediating role of corporate social responsibility: A structural equation modelling approach. International Business Research, 10(1), 199-221. doi:10.5539/ibr.v10n1p199

Alrubaiee, L., Alzubi, H. M., Hanandeh, R. E., \& Al Ali, R. (2015). Investigating the relationship between knowledge management processes and organizational performance, the mediating effect of organizational innovation. International Review of Management and Business Research, 4(4 Part 1), 989-1009.

Andreeva, T., \& Kianto, A. (2011). Knowledge processes, knowledge-intensity and innovation: A moderated mediation analysis. Journal of Knowledge Management, 15(6), 1016-1034. doi:10.1108/13673271111179343

Bagozzi, R. P., \& Yi, Y. (1988). On the evaluation of structural equation models. Journal of the Academy of Marketing Science, 16(1), 74-94. doi:10.1007/BF02723327

Biygautane, M., \& Al-Yahya, K. (2011). Knowledge Management in the UAE's Public Sector: The Case of Dubai. Gulf Research Meeting Conference at the University of Cambridge.

Bolen, K., Hwang, J., \& Wunker, S. (2009). Swallowing the innovator's prescription: How pharma can use disruptive innovation to capitalize on healthcare reform. Pharmaceutical Executive, 55-59.

Buckley, P. R., \& Malady, L. (2015). Building Consumer Demand for Digital Financial Services-The New Regulator Frontier. The Journal of Financial Perspective, 3(3), 1-36.

Bueno, E., Rodriguez Anton, J. M., \& Salmador, M. P. (2008). Knowledge creation as a dynamic capability: Implications for innovation management and organisational design. International Journal of Technology Management, 4l(1-2), 155-168. doi:10.1504/IJTM.2008.015989

Byukusenge, E., Munene, J., \& Orobia, L. (2016). Knowledge management and business performance: Mediating effect of innovation. Journal of Business and Management Sciences, 4(4), 82-92.

Chesbrough, H. (2010). Business model innovation: Opportunities and barriers. Long Range Planning, 43(2), 354-363. doi:10.1016/j.lrp.2009.07.010 
Crossan, M. M., \& Apaydin, M. (2010). A multi-dimensional framework of organizational innovation: A systematic review of the literature. Journal of Management Studies, 47(6), 1154-1191. doi:10.1111/j.14676486.2009.00880.x

Dahiyat, S. E. (2015). An integrated model of knowledge acquisition and innovation: Examining the mediation effects of knowledge integration and knowledge application. International Journal of Learning and Change, 8(2), 101-135. doi:10.1504/IJLC.2015.074064

David-West, Umukoro, \& Iheanachor. (2018). Branchless banking and financial inclusion: A Global Perspective on Digital Banking Consumer Behavior. .10.4324/9781351174466-11

Davoudi, S. M. M., Fartash, K., Zakirova, V. G., Belyalova, A. M., Kurbanov, R. A., Boiarchuk, A. V., \& Sizova, Z. M. (2018). Testing the Mediating Role of Open Innovation on the Relationship between Intellectual Property Rights and Organizational Performance: A Case of Science and Technology Park. Eurasia Journal of Mathematics, Science and Technology Education, 14(4), 1359-1369. doi:10.29333/ejmste/83651

Edwards-Schachter, M. (2018). The nature and variety of innovation. International Journal of Innovation Studies, 2(2), 65-79. doi:10.1016/j.jijs.2018.08.004

Efrat, K., Gilboa, S., \& Yonatany, M. (2017). When marketing and innovation interact: The case of born-global firms. International Business Review, 26(2), 380-390. doi:10.1016/j.ibusrev.2016.09.006

Ellis, P. D. (2010). International trade intermediaries and the transfer of marketing knowledge in transition economies. International Business Review, 19(1), 16-33. doi:10.1016/j.ibusrev.2009.09.005

Falahati, A., Jamshidi Navid, B., Khosravi, S., \& Koolivand, P. (2013). Effect of marketing knowledge management on organizational performance: A Case study in Iran insurance company of Kermanshah. European Online Journal of Natural and Social Sciences, 2(4), 609.

Fang, Y., Jiang, G. L. F., Makino, S., \& Beamish, P. W. (2010). Multinational firm knowledge, use of expatriates, and foreign subsidiary performance. Journal of Management Studies, 47(1), 27-54. doi:10.1111/j.14676486.2009.00850.x

Fidel, P., Cervera, A., \& Schlesinger, W. (2016). Customer's role in knowledge management and the innovation process: Effects on innovation capacity and marketing results. Knowledge Management Research and Practice, 14(2), 195-203. doi:10.1057/kmrp.2015.19

Foumani, S. A., \& Chirani, E. (2012). Marketing knowledge management in business organizations. Arabian Journal of Business and Management Review, 1(1), 44-49.

Girniene, I. (2013). Knowledge management influence on innovation: Theoretical analysis of organizational factors. Proceeding from the European Conference on Knowledge Management, 2, 877-885.

Gomber, P., Koch, J.-A., \& Siering, M. (2017). Digital Finance and FinTech: Current research and future research directions. Journal of Business Economics., 87(5), 45-55. doi:10.1007/s11573-017-0852-x

Grant, R. (1996). Toward A Knowledge-Based Theory of the Firm. Strategic Management Journal, 17(S2), 109-122. doi:10.1002/smj.4250171110

Hair, J. F., Anderson, R. E., Tatham, R. L., \& Black, W. C. (2006). Multivariate Data Analysis (5th ed.). Pearson Education Incorporation.

Hair, J. F. Jr, Black, W. C., Babin, B. J., \& Anderson, R. E. (2010). Multivariate data analysis (7th ed.). Pearson Education International.

Hanvanich, S., Droge, C., \& Calantone, R. (2003). Reconceptualizing the meaning and domain of marketing knowledge. Journal of Knowledge Management, 7(4), 124-135. doi:10.1108/13673270310492994

Harem, H., \& Al-Saae'd, R. (2006). Organizational culture and its impact on knowledge generation: A field study of Jordanian commercial banks. Jordan Journal of Business Administration, 2(2), 225-245. https://pdfs. semanticscholar.org/8433/ef2a93f5e8d1bee2201684ae0ae6edea0e61.pdf

Ismail, M. B., \& Yusof, Z. M. (2009). Demographic factors and knowledge sharing quality among Malaysian government officers. Communications of the IBIMA, 9(1), 1-8. 
Kermally, S. (2019). Marketing and Economics. Vernon Press.

Klapper, L., El-Zoghbi, M., \& Hess, J. (2016). Achieving sustainable development goals: The role of financial inclusion. CGAP.

Kör, B., \& Maden, C. (2013). The relationship between knowledge management and innovation in Turkish Service and High-Tech Firms. International Journal of Business and Social Science, 4(4), 293-304.

Korir, M. C., Sang, W., Shisia, A., \& Mutung'u, C. (2015). Financial Innovations and Performance of Commercial Banks in Kenya. International Journal of Economics. Commerce and Management, 3(5), 1242-1265.

Leal-Rodríguez, A., Leal-Millán, A., Roldán-Salgueiro, J. L., \& Ortega-Gutiérrez, J. (2013). Knowledge management and the effectiveness of innovation outcomes: The role of cultural barriers. Electronic Journal of Knowledge Management, 11, 62-71.

Leposky, T., Arslan, A., \& Kontkanen, M. (2017). Determinants of reverse marketing knowledge transfer potential from emerging market subsidiaries to multinational enterprises' headquarters. Journal of Strategic Marketing, 25(7), 567-580. doi:10.1080/0965254X.2016.1195856

Liebl, F. (2015). Knowledge management for strategic marketing. In Assessing the different roles of marketing theory and practice in the jaws of economic uncertainty (pp. 48-57). Springer. doi:10.1007/978-3-319-11845-1_18

Lungu, V. (2019). Knowledge-based society-a condition to ensure sustainable development. Eastern European Journal for Regional Studies, 5(1), 96-111.

Mabrouk, A., \& Mamoghli, C. (2016, October). Dynamic of Financial Innovation and Performance of Banking Firms: Context of an Emerging Banking Industry. International Research Journal of Finance and Economics, (51), 17-37.

Mansur, C. M., Suliyanto, S., \& Rahab, R. (2019). Value of innovation and marketing performance. International Review of Management and Marketing, 9(3), 127-133. doi:10.32479/irmm.7761

Masa'deh, R. E., Almajali, D. A., Alrowwad, A. A., \& Obeidat, B. (2019). The role of knowledge management infrastructure in enhancing job satisfaction: A developing country perspective. Interdisciplinary Journal of Information. Knowledge \& Management, 14, 32-45.

Massa, L., \& Tucci, C. L. (2013). Business model innovation. The Oxford Handbook of Innovation Management, 420-441.

McIver, D., \& Lepisto, D. A. (2017). Effects of knowledge management on unit performance: Examining the moderating role of tastiness and learnability. Journal of Knowledge Management, 21(4), 796-816. doi:10.1108/ JKM-08-2016-0347

Morgan, N. A. (2012). Marketing and business performance. Journal of the Academy of Marketing Science, 40(1), 102-119. doi:10.1007/s11747-011-0279-9

Moustaghfir, K. (2008). The dynamics of knowledge assets and their link with firm performance. Measuring Business Excellence, 12(2), 10-24. doi:10.1108/13683040810881162

Muddaha, G., Yeoh, K.K., \& Sulaiman, Y. (2018). Impact of management capabilities and environmental dynamism on Nigerian SMEs marketing innovation performance. International Journal of Management Research \& Review, 8, 120-35.

Muthinja, M. M. (2016). Financial innovations and bank performance in Kenya: evidence from branchless banking models (PhD thesis). School of Economic and Business Sciences, University of the Witwatersrand, Johannesburg.

Nguena, C. L. (2019). Mobile financial and banking services development in Africa (Working Paper Series 323). Abidjan: African Development Bank Group.

Ojha, A. K. (2005). Impact of team demography on knowledge sharing in software project teams. South Asian Journal of Management, (12), 67-78.

Oliva, F., \& Kotabe, M. (2019). Barriers, practices, methods and knowledge management tools in startups. Journal of Knowledge Management, 23(9), 1838-1856. Advance online publication. doi:10.1108/JKM-06-2018-0361 
Prifti, R., \& Alimehmeti, G. (2017). Market orientation, innovation, and firm performance: An analysis of Albanian firms. Journal of Innovation and Entrepreneurship, 6(1), 8. doi:10.1186/s13731-017-0069-9

Rahimi, A., Cohn, T., \& Baldwin, T. (2018). Semi-supervised user geolocation via graph convolutional networks. arXiv preprint arXiv:1804.08049

Ramona-Diana, L., \& Bolisani, E. (2016). The nexus between knowledge management and innovation. A literature reviews. Opportunities and Risks in the Contemporary Business Environment, 662680.

Rezaee, F., \& Jafari, M. (2015). The effect of marketing knowledge management on sustainable competitive advantage: Evidence from the banking industry. Accounting, 1(2), 69-88. doi:10.5267/j.ac.2015.12.002

Ritala, P., Huotari, P., Bocken, N. M. P., Albareda, L., \& Puumalainen, K. (2018). Sustainable business model adoption among SandP 500 firms: A longitudinal content analysis study. Journal of Cleaner Production, 170, 216-226. doi:10.1016/j.jclepro.2017.09.159

Scott, S., Reenen, J., \& Zachariadis, M. (2017). The long-term effect of digital innovation on bank performance: An empirical study of SWIFT adoption in financial services. Research Policy, 46(5), 984-1004. doi:10.1016/j. respol.2017.03.010

Sekaran, U. (2003). Research Methods for Business: A Skill Building Approach (4th ed.). John Wiley \& Sons Inc.

Silber, J. (1993). Inequality Decomposition by Income Source: A Note. The Review of Economics and Statistics, 75(3), 545-547. doi:10.2307/2109473

Talat. (2018). How do high-performance work systems affect individual outcomes? A multi-level perspective. Frontiers in Psychology, 9(586), 1-13.

Torabi, F., \& El-Den, J. (2017). The impact of knowledge management on organizational productivity: A case study on Koosar Bank of Iran. Procedia Computer Science, 124, 300-310. doi:10.1016/j.procs.2017.12.159

Watson, S., \& Hewett, K. (2006). A multi-theoretical model of knowledge transfer in organizations: Determinants of knowledge contribution and knowledge reuse. Journal of Management Studies, 43(2), 141-173. doi:10.1111/ j.1467-6486.2006.00586.x

Wessel, M., \& Christensen, C. M. (2012). Surviving Disruption. Harvard Business Review, 90, 56-64.

Yin, R., \& Zhengzheng, L. (2010). How commercial banks implement financial innovations: A case from the retail operation of the Bank of China. Academic Press.

Hani H. Al-Dmour's background is in international marketing and his particular research interests surround the export marketing behavior and services marketing. He completed university education and received bachelor's degree Business Management from the University of Jordan in 1983 and MBA degree from the University of Edinburgh in 1986. In 1985, he gained his Ph.D. degree from the University of Sheffield in export marketing behaviour in 1993.

Futon Alsfour has her MBA from the University of Jordan.

Rand Al-Dmour is an assistant professor at Management Information System Department, School of Business at the University of Jordan. She holds a bachelor's degree in Management Information System and MBA/Management Degree from the University of Jordan. She also has a PhD degree from Brunel university, London, UK in 2012. Her current research interest is in the area of information system, innovation, human resources information system, management information system. Apart of her work, she has been published in reputable journals including IJBR, IJMSBS, EJBM, ESJ, IJMS. 